\title{
Characterization of Petroleum Sludge from Refinery Industry Biological Wastewater Treatment Unit
}

\author{
Abubakar M. Ali ${ }^{1}$, Mohd A. Abu-Hassan ${ }^{2}$, Raja R.K. Ibrahim ${ }^{3}$, Muhammad. A. A. Zaini ${ }^{4}$, Bala I. \\ Abdulkarim ${ }^{5}$, Ali S. Hussein ${ }^{6}$, Sheila M. Su , and Muhd Azril I. Mohd Halim ${ }^{8}$ \\ Department of Chemical Engineering, Faculty of Chemical and Energy Engineering. Universiti \\ Teknologi Malaysia. Skudai, 81310 Johor, Malaysia. \\ ${ }^{1}$ Department of Chemical Engineering, Kaduna Polytechnic, Kaduna, Nigeria \\ ${ }^{5}$ Department of Chemical Engineering, University of Abuja, Nigeria \\ Corresponding: abualimoh67@gmail.com
}

\begin{abstract}
Thermal plasma technique is becoming prominent in the treatment of variety of waste ranging from municipal solid waste, incinerator residue, hospital waste, electronics waste and industrial sludge. Application of the new treatment technology to petroleum sludge requires information on the nature and characteristics of the sludge that will be use to optimize the treatment system. In this investigation, petroleum sludge obtained from Petronas Melaka was characterized for its physical and chemical features. Proximate and ultimate analysis as well as determination of elemental composition were carried out. The sludge was found to contain high moisture $(78.91 \%)$, low ash $(5.06 \%)$, low volatiles $(5.52 \%)$ and high fixed carbon $(10.51 \%)$. The sludge has a TOC of $54.48 \%$ and $\mathrm{HHV}$ of $23.599 \mathrm{MJ} / \mathrm{kg}$. Despite the high moisture content, the higher heating value (HHV) is high when compared to literature values. The high value of HHV may be associated with the high fixed carbon, low ash content and high value of TOC. The apparent density of the sludge is slightly lower. Fourteen heavy metals are detected in significant quantities. Proper waste management that will safely dispose the sludge is required. The waste disposal technique should take into cognizant the possibility of leaching of heavy metals into ground water on one hand and the gasification of lighter ones as exhaust gas on the other.
\end{abstract}

Keywords: petroleum sludge, characterization, total organic carbon, metal concentration

\section{Introduction}

Upstream and downstream operations in petroleum industry generate tremendous quantities of petroleum sludge ${ }^{1}$. Large quantities of water is utilized at different stages of petroleum processing such as desalting, distillation, thermal cracking and catalytic cracking thereby producing large volume of wastewater. Petroleum refining process is said to generate wastewater of about 1.6 times the volume of crude oil processed ${ }^{2}$. These wastewater contain hydrocarbons, phenols and dissolved minerals ${ }^{3}$. The hydrocarbons which are generally benzene, toluene, ethyl benzene and xylenes (BTEX) are either toxic or carcinogenic ${ }^{4}$. Phenols and dissolved minerals are also toxic to both human and aquatic life ${ }^{5}$. Thus, the Environmental Protection Agency regulations for petroleum wastewater treatment prior to disposal ${ }^{6}$.

Methods employed for petroleum wastewater treatment include electrocoagulation ${ }^{7}$, electrochemical oxidation ${ }^{8}$, dissolved air floatation ${ }^{9}$ and biological treatment ${ }^{10}$. However, a secondary waste (petroleum sludge) that requires further treatment is generated from both the physical processes and the biological treatment. Petroleum sludge is also generated from cleaning of oil storage tanks, from oil-water separators, from cleaning of processing equipment, and also from cleaning of oil-spill at both drilling and refining sites ${ }^{11}$.

Petroleum sludge vary in composition depending on the origin and storage condition ${ }^{12}$. Generally, it contains about 10 - 30 wt.\% hydrocarbons, 5 - 20 wt.\% solids and 50 - 85 wt.\% water 
13. Traditionally, petroleum sludge is disposed-off using biological treatment method such as land farming and composting ${ }^{14}$. These treatment techniques have adverse effect on man and environment ${ }^{15}$ hence the need for a safer and more environmentally friendly techniques. Drying followed closely by incineration is a more recent technique adopted for petroleum sludge management. The incineration technique is characterize with the emission of low molecular polycyclic aromatic hydrocarbons (PAHs), greenhouse gases $\left(\mathrm{CO}_{2}\right.$ and $\left.\mathrm{CH}_{4}\right)$ and other harmful gases (dioxins and furans) ${ }^{16}$. Thermal plasma treatment of petroleum sludge, an environmentally safe waste treatment technique, is therefore proposed.

Prior to the treatment of petroleum sludge in thermal plasma, there is need for firsthand information on the characteristics of the sludge; the moisture content, the heating value, carbon content and other inorganics present, that will guide the selection and optimization of treatment technique. Documented reports on characterization of petroleum sludge provided information on structural composition ${ }^{14,17-18}$ and physicochemical characteristics ${ }^{15}$. There is need for further information regarding the elemental composition (metal and nonmetal) as well as the surface morphology. Such information will guide the choice of plasma operating temperature for effective partitioning of heavy metals between solid and gaseous products and also provide basis for comparison of products characteristics with the parent material. It is in this light that characterization of petroleum sludge from Petronas Melaka is carried out.

\section{Materials and Methods}

\subsection{Material}

Petroleum sludge was obtained from Petronas Refinery Plant located in Sungai Udang, Melaka. Oil spills, waste from bottom of storage tanks and wastewater from different process equipment are treated at the refinery wastewater treatment unit using biological process. The liquid effluent is discharged while the sludge from the bottom of a clarifier is sent to sludge management unit where other treatment processes like stabilization takes place. From the management unit the sludge is sent to filter press to further remove water to the barest minimum. The sludge used in this analysis is a black semi-solid cake collected from the filter press. It is hazardous and classified as schedule waste (SW204).

\subsection{Characterization}

The method used for proximate and ultimate analysis were adopted from Calvo, et al. ${ }^{19}$. Percentage moisture was determined gravimetrically by the oven-drying method (ASTMD 317311). Higher Heating Value (HHV) at constant volume was determined using Isoperibol bomb calorimeter (Model AC-350) via the equivalent methods (ASTM D 2015). Ash content and volatile matter were determined gravimetrically in a muffle furnace (Barnstead thermolyne furnace 1400) via test method ASTM D3174-11 and ASTM D3175-11 respectively. Percent fixed carbon was calculated in accordance to ASTM D3172-07a. Ultimate analysis of dried sludge was conducted using CHNS/O analyzer via the standard method ASTM D5373 and ASTM D4239.

Metals concentration in the sludge sample were analyzed via acid digestion of the dried sludge according to US EPA method 3050B. Total organic carbon (TOC) was measured using Total Organic Carbon - Solid Sample Module (TOC-SSM) machine (Model: SSM-500A). Glucose is used as standard for total carbon (TC) measurement while sodium carbonate was used as standard for inorganic carbon (IC) measurement. Finally, TOC was calculated as the difference between the results of the measurements of TC and IC. 
Metals concentration in the sludge sample were analyzed via acid digestion of the dried sludge according to US EPA method 3050B. Measurement of $\mathrm{Al}, \mathrm{As}, \mathrm{Ba}, \mathrm{Cd}, \mathrm{Cr}, \mathrm{Cu}, \mathrm{Fe}, \mathrm{Pb}, \mathrm{Mg}$, $\mathrm{Mn}, \mathrm{Ni}, \mathrm{K}, \mathrm{Si}, \mathrm{Ag}, \mathrm{Zn}$ and $\mathrm{Hg}$ was done using Inductively Coupled Plasma Optical Emission Spectrophotometer (ICPOES) (Agilent, model: 710) while that of $\mathrm{Cr}, \mathrm{Cu}, \mathrm{Fe}, \mathrm{Zn}, \mathrm{Mg}$ and $\mathrm{Na}$ was done using Flame Atomic Absorption Spectrometer (AAS) (Perkin Elmer, model: PinAAcle 900T). The sludge sample was digested prior to ICPOES and AAS analysis. $5 \mathrm{~g}$ of sample was digested with $7 \mathrm{ml}$ of $65 \% \mathrm{HNO}_{3}$ and $1 \mathrm{ml}$ of $30 \% \mathrm{H}_{2} \mathrm{O}_{2}$ in a microwave oven digester (Milestone, model SK-10). The digestion was done in duplicate, one at $200^{\circ} \mathrm{C}$ and the other at $110^{\circ} \mathrm{C}$, for 15 min each.

\section{Result and Discussion}

Sludge sample used for this study was collected from the filter press of the drying unit after the biological treatment of wastewater. The sludge is a black semi-solid cake. The sample was stored under cold condition to maintain its characteristics. Structural components analysis (proximate analysis) and ultimate analysis are respectively shown in Table 1 and 2 . The moisture (78.91\%) is in close range with 75.3\% reported by Mokhtar, et al. ${ }^{17}$ and $78.25 \%$ reported by Aida, et al. ${ }^{18}$. The low volatile matter $(5.52 \%)$ is an indication of more aromatic structures and less functional groups.

A total weight loss of $92 \%$ was recorded in the TGA result shown in Figure 1. Evaporation of moisture was observed to occur between $50{ }^{\circ} \mathrm{C}$ and $125^{\circ} \mathrm{C}$ as seen in the TG curve. Due to large volume of moisture the DTG was observed to increase sharply to a peak at $100{ }^{\circ} \mathrm{C}$. Between 100 and $150{ }^{\circ} \mathrm{C}$ there is reduction in weight lost when compare to the earlier stage (between 50 and $100{ }^{\circ} \mathrm{C}$ ). This region is also reflected in the DTG curve with a sharp fall. This observation could be attributed to the evaporation of the remaining moisture and the volatilization of small quantity of low temperature hydrocarbons. Decomposition was observed to occur between 150 and $450{ }^{\circ} \mathrm{C}$, as seen in the gradual decrease in the TG curve. Most of the hydrocarbon in the sludge have their boiling points within this range. The DTG curve was seen to slightly rise and fall, this is because the hydrocarbon components have different boiling points and different concentrations in the sludge. Therefore change in weight loss with temperature may not be the same throughout the range.

Table 1: Proximate Analysis of petroleum wastewater sludge (wt. \%)

\begin{tabular}{lll}
\hline Analyses & Test result & Mokhtar, et al. ${ }^{\mathbf{1 7}}$ \\
\hline Moisture content (wt. \%) & 78.91 & 75.3 \\
Ash content (wt. \%) & 5.06 & 6.7 \\
Volatile matter (wt. \%) & 5.52 & 9.9 \\
Fixed carbon (wt. \%) & 10.51 & 8.1 \\
Apparent density (g/ml) & 1.08 & 1.13 \\
HHV (MJ/kg) & 23.599 & 20.500 \\
\hline
\end{tabular}

Higher heating value of $23.599 \mathrm{MJ} / \mathrm{kg}$ was obtained which is higher than the value in literature ${ }^{17}$ and this value is within the range of HHV of coal ${ }^{20}$. The high HHV value recorded may be attributable to the high fixed carbon and lower ash content of the sludge. Apparent density of the sludge was determined through volume displacement of known mass of sludge. The apparent density is $1.08 \mathrm{~g} / \mathrm{ml}$ and is lower than $1.13 \mathrm{~g} / \mathrm{ml}$ reported by Mokhtar, et al. ${ }^{17}$. 


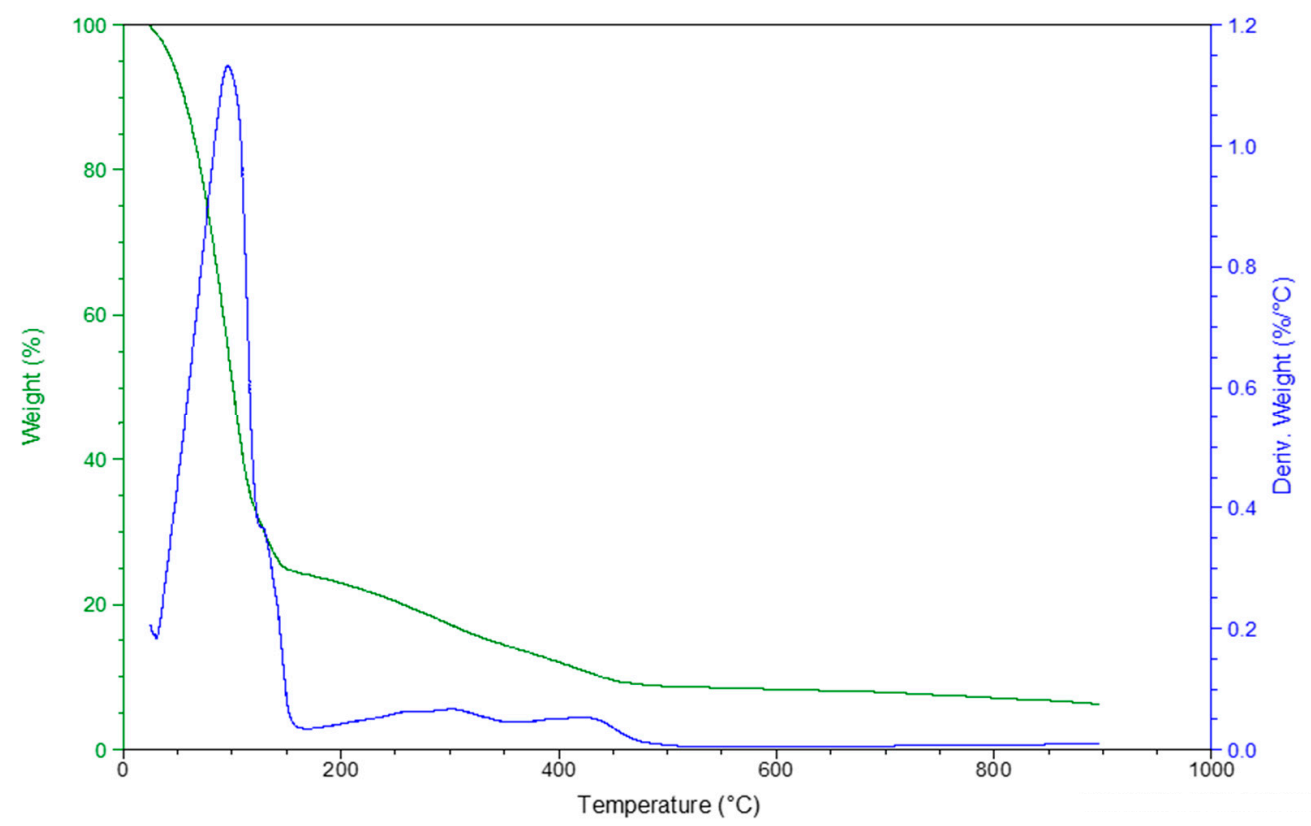

Figure 1: TGA curves for wet petroleum sludge at $900{ }^{\circ} \mathrm{C}$

The hydrocarbon elements (hydrogen and carbon) and oxygen constitute about $94.5 \%$, while nitrogen and sulfur account for 5.5\%. Wastewater from petroleum processing contained high amount of hydrocarbons. After series of physical, chemical and biological treatment the organic content is drastically reduced. Eventually, the residual sludge from the wastewater treatment bears most of the hydrocarbon. The combine values of nitrogen and sulfur, as shown in Table 2, is lower when compare to values reported by Mokhtar, et al. ${ }^{17}$. These two elements are responsible for formation of poisonous gases (NOx and SOx) during combustion. As such, thermal decomposition and products gas cooling need to be properly controlled to prevent reformation of such poisonous gases. Total organic carbon (TOC) account for $54.48 \%$ out of the $54.49 \%$ total carbon (TC). This implies that the bulk of the carbon can be utilized in the formation of hydrocarbons like fuel gases or organic chemicals and in energy generation.

Table 2: Ultimate analysis of petroleum wastewater sludge (wt \%) and TOC (\%)

\begin{tabular}{lllllll}
\hline & C (wt.\%) & H (wt.\%) & N (wt.\%) & S (wt.\%) & O (wt.\%) & TOC (wt.\%) \\
\hline Test result & 51.4 & 7.3 & 3.3 & 2.2 & 35.8 & 54.48 \\
$\begin{array}{l}\text { Mokhtar, et al. } \\
17\end{array}$ & 45.00 & 6.60 & 7.00 & 1.70 & 39.70 & - \\
\hline
\end{tabular}

Ten (10) heavy metals, as shown in Table 3, were detected in the sludge sample using Perkin Elmer AAS (model PinAAcle900T). All the elements, with the exception of $\mathrm{Hg}$, are within the regulatory limit for wastewater disposal. However, concentration of $\mathrm{Hg}(0.139081 \mathrm{mg} / \mathrm{l})$ is very high when compared with the regulatory limit of $0.00003 \mathrm{mg} / \mathrm{l}$. High content of aluminum could 
be attributed to the use of aluminum compounds as flocculants. Presence of chromium, zinc, aluminum automatically classified the sludges as schedule waste SW204 ${ }^{21}$

Table 3: Heavy metals concentration in raw petroleum sludge

\begin{tabular}{ccc}
\hline Heavy metal & Concentration $(\mathbf{m g} / \mathbf{l})$ & Standard for wastewater $(\mathbf{m g} / \mathbf{l}){ }^{\mathbf{2 2}}$ \\
\hline $\mathrm{Na}$ & 0.210 & - \\
$\mathrm{Mg}$ & 0.150902 & 0.20 \\
$\mathrm{Al}$ & 1.58504 & - \\
$\mathrm{K}$ & 0.283544 & - \\
$\mathrm{Cr}$ & 0.016197 & 0.05 \\
$\mathrm{Mn}$ & 0.013721 & 0.20 \\
$\mathrm{Fe}$ & 1.13897 & 5.00 \\
$\mathrm{Zn}$ & 0.124 & - \\
$\mathrm{Ag}$ & 0.046303 & 0.10 \\
$\mathrm{Hg}$ & 0.139081 & 0.00003 \\
\hline
\end{tabular}

SEM images of the sludge was captured using variable pressure scanning electron microscope (VP-SEM) at two magnifications (300 and 1000). The images for the sludge sample shown in Figure 2. Both images, A and B, showed a buildup (one upon another) of discontinuous layers of materials with a lot of void spaces and hollows.

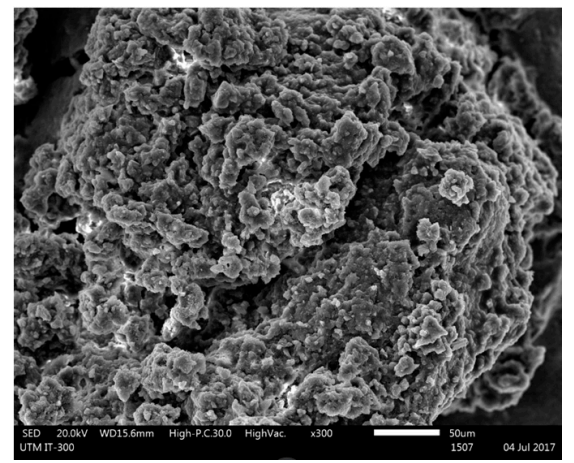

A

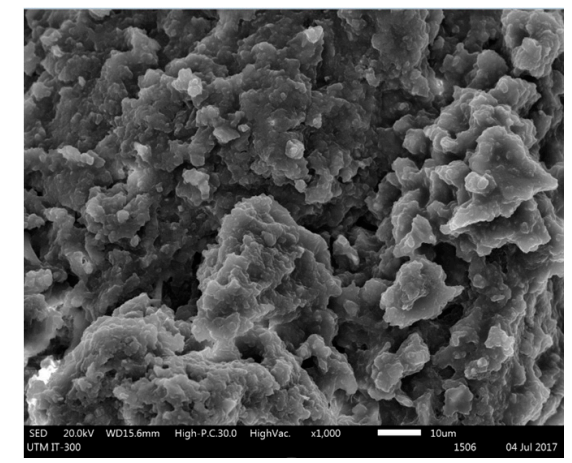

B

Figure 2: SEM images of petroleum sludge at two magnifications. (A) SED 20kV, WD $15.5 \mathrm{~mm}$, (X 300), $(50 \mu \mathrm{m}),(\mathrm{B})$ SED 20kV, WD 15.5mm, (X 1000), (10 $\mu \mathrm{m})$

\section{Conclusion}

Sample of petroleum sludge from Petronas Melaka, Malaysia was characterized to determine the properties that will be used for optimization of process equipment for treatment of the sludge. From the characterization, the black oily sludge has $78.91 \%$ moisture, $5.06 \%$ ash, $5.52 \%$ volatile matter, $10.51 \%$ fixed carbon and $54.48 \%$ TOC. Despite the high moisture content, the dried sludge has a higher heating value (HHV) of $23.599 \mathrm{MJ} / \mathrm{kg}$. The high value of HHV may be related to the high fixed carbon, low ash content and high value of TOC. The apparent density of the sludge is $1.08 \mathrm{~g} / \mathrm{ml}$. Heavy metals detected in the sludge are $\mathrm{Na}, \mathrm{Mg}, \mathrm{Al}, \mathrm{K}, \mathrm{Cr}, \mathrm{Mn}, \mathrm{Fe}, \mathrm{Zn}$, $\mathrm{Ag}$ and $\mathrm{Hg}$. With the exception of $\mathrm{Hg}$ the concentration of the metals were found to be within standard. $\mathrm{Hg}$ has a concentration of $0.139081 \mathrm{mg} / \mathrm{L}$ which is much higher than standard. Waste 
disposal technique should take into cognizant the possibility of leaching heavy metals into ground water on one hand and the gasification of lighter ones as exhaust gas on the other.

\section{References}

1. Islam, B., Petroleum Sludge, Its Treatment and Disposal : A Review. Int. J. Chem. Sci. 2015, 13 (4), 1584-1602.

2. Coelho, A.; Castro, A. V.; Dezotti, M.; Sant'Anna, G. L., Treatment of petroleum refinery sourwater by advanced oxidation processes. Journal of hazardous materials 2006, 137 (1), 178184.

3. Diya'uddeen, B. H.; Wan-Daud, W. M. A.; Abdul-Aziz, A. R., Treatment technologies for petroleum refinery effluents: a review. Process Safety and Environmental Protection 2011, 89 (2), 95-105.

4. de Mello, J. M. M.; de Lima, B. H.; de Souza, A. A. U.; da Silva, A.; Ulson, S. M. d. A. G., Biodegradation of BTEX compounds in a biofilm reactor-modeling and simulation. Journal of Petroleum Science and Engineering 2010, 70 (1), 131-139.

5. Tang, X.; Eke, P. E.; Scholz, M.; Huang, S., Processes impacting on benzene removal in vertical-flow constructed wetlands. Bioresource technology 2009, 100 (1), 227-234.

6. Leavitt, M.; Grumbles, B.; Grubbs, G. H.; Smith, M.; Wall, T.; Goodwin, J.; Johnston, C.; Matuszko, J., Technical support document for the 2004 Effluent Guidelines Program plan. Environmental Protection, US 2004.

7. El-Naas, M. H.; Al-Zuhair, S.; Al-Lobaney, A.; Makhlouf, S., Assessment of electrocoagulation for the treatment of petroleum refinery wastewater. Journal of environmental management 2009, 91 (1), 180-185.

8. Yan, L.; Ma, H.; Wang, B.; Wang, Y.; Chen, Y., Electrochemical treatment of petroleum refinery wastewater with three-dimensional multi-phase electrode. Desalination 2011, 276 (1), 397-402.

9. Hami, M. L.; Al-Hashimi, M. A.; Al-Doori, M. M., Effect of activated carbon on BOD and COD removal in a dissolved air flotation unit treating refinery wastewater. Desalination 2007, 216 (1-3), 116-122.

10. Mazzeo, D. E. C.; Levy, C. E.; de Angelis, D. d. F.; Marin-Morales, M. A., BTEX biodegradation by bacteria from effluents of petroleum refinery. Science of the Total Environment 2010, 408 (20), 4334-4340.

11. Wang, Z.; Guo, Q.; Liu, X.; Cao, C., Low temperature pyrolysis characteristics of oil sludge under various heating conditions. Energy \& fuels 2007, 21 (2), 957-962.

12. Kriipsalu, M.; Marques, M.; Maastik, A., Characterization of oily sludge from a wastewater treatment plant flocculation-flotation unit in a petroleum refinery and its treatment implications. Journal of Material Cycles and Waste Management 2008, 10 (1), 79-86.

13. Speight, J. G., The refinery of the future. William Andrew: 2010.

14. Al-Futaisi, A.; Jamrah, A.; Yaghi, B.; Taha, R., Assessment of alternative management techniques of tank bottom petroleum sludge in Oman. Journal of hazardous materials 2007, 141 (3), 557-564.

15. Asia, I. O.; Enweani, I. B.; Eguavoen, I. O., Characterization and treatment of sludge from the petroleum industry. African Journal of Biotechnology 2006, 5 (5), 461-466.

16. Hu, G.; Li, J.; Zeng, G., Recent development in the treatment of oily sludge from petroleum industry: A review. Journal of hazardous materials 2013, 261, 470-490. 
17. Mokhtar, N. M.; Omar, R.; Salleh, M. A. M.; Idris, A., Characterization of sludge from the wastewater-treatment plant of a refinery. International Journal of Engineering and Technology 2011, 8 (2), 48-56.

18. Aida, I. M. I.; Rozita, O.; Salmiaton, A., Vitrification of Petrochemical Sludges Containing Heavy Metals. SEGi Review 2012, 5 (1), 89-94.

19. Calvo, L. F.; García, A. I.; Otero, M., An Experimental Investigation of Sewage Sludge Gasification in a Fluidized Bed Reactor. The Scientific World Journal 2013, 2013.

20. Demirbas, A., Sustainable cofiring of biomass with coal. Energy conversion and management 2003, 44 (9), 1465-1479.

21. Waste, M. E. S., Environmental Quality Act 1974. Environmental Quality (Scheduled Wastes). 2005; Vol. Regulations 2005.

22. Barakat, M. A., New trends in removing heavy metals from industrial wastewater. Arabian Journal of Chemistry 2011, 4 (4), 361-377. 